\title{
Predictive modelling of the spatial pattern of past and future forest cover changes in India
}

\author{
C Sudhakar Reddy ${ }^{1, *}$, Sonali Singh ${ }^{1,2}, \mathrm{~V}$ K Dadhwal ${ }^{1,2}, \mathrm{C}$ S Jha ${ }^{1}$, \\ N RAMA RAO ${ }^{2}$ and $\mathrm{P}$ G DIWAKAR ${ }^{1}$ \\ ${ }^{1}$ National Remote Sensing Centre, Indian Space Research Organisation, Balanagar, Hyderabad 500 037, India. \\ ${ }^{2}$ Department of Earth and Space Sciences, Indian Institute of Space Science and Technology, Valiamala, \\ Thiruvananthapuram 695 547, India. \\ *Corresponding author.e-mail: drsudhakarreddy@gmail.com
}

This study was carried out to simulate the forest cover changes in India using Land Change Modeler. Classified multi-temporal long-term forest cover data was used to generate the forest covers of 1880 and 2025. The spatial data were overlaid with variables such as the proximity to roads, settlements, water bodies, elevation and slope to determine the relationship between forest cover change and explanatory variables. The predicted forest cover in 1880 indicates an area of 10,42,008 $\mathrm{km}^{2}$, which represents $31.7 \%$ of the geographical area of India. About $40 \%$ of the forest cover in India was lost during the time interval of 1880-2013. Ownership of majority of forest lands by non-governmental agencies and large scale shifting cultivation are responsible for higher deforestation rates in the Northeastern states. The six states of the Northeast (Assam, Manipur, Meghalaya, Mizoram, Nagaland, Tripura) and one union territory (Andaman \& Nicobar Islands) had shown an annual gross rate of deforestation of $>0.3$ from 2005 to 2013 and has been considered in the present study for the prediction of future forest cover in 2025. The modelling results predicted widespread deforestation in Northeast India and in Andaman \& Nicobar Islands and hence is likely to affect the remaining forests significantly before 2025 . The multilayer perceptron neural network has predicted the forest cover for the period of 1880 and 2025 with a Kappa statistic of $>0.70$. The model predicted a further decrease of $2305 \mathrm{~km}^{2}$ of forest area in the Northeast and Andaman \& Nicobar Islands by 2025. The majority of the protected areas are successful in the protection of the forest cover in the Northeast due to management practices, with the exception of Manas, Sonai-Rupai, Nameri and Marat Longri. The predicted forest cover scenario for the year 2025 would provide useful inputs for effective resource management and help in biodiversity conservation and for mitigating climate change.

\section{Introduction}

Within the climate change mitigation framework, prediction of deforestation is essential for the application of the United Nations Framework Convention on the Climate Change REDD+ Programme, which aims at reducing emissions from deforestation and forest degradation (Olander et al. 2008).
The rate of forest loss was reported as 3 Mha per year between 1990 and 2000 and of 6 Mha per year between 2000 and 2005 (FAO 2005). In addition to this, the global gross forest cover loss was reported to be $0.6 \%$ per year during 2000-2005 (Hansen et al. 2010). India's forests, combined with its biological and social distinctiveness, suggests that forest monitoring should be a continuing

Keywords. Deforestation; Land Change Modeler; multi-layer perceptron neural network; India. 
practice. In the past, forest cover has been decreasing in India constantly due to the lack of foresight and priorities of the policy makers. In the 17th century British India, the forests were over-exploited and destroyed. Large scale deforestation occurred during the period 1880-1950, due to British rule policies to increase income from the timber products and cropland. The concern of the Government up to and even after independence in 1947 was to clear forests for cropland and developmental activities (Ribbentrop 1990). Greater deforestation was recorded due to construction of the Indian railway network during the 1870's period (Gadgil and Guha 1993). It was calculated that over a million sleepers were required annually, which led to the massive felling of sal (Shorea robusta) in central India and teak (Tectona grandis) in south India (Meher-Homji 1989).

Richards and Flint (1994) estimated the state-wise forest carbon stock over India for the year 1880 and used a population-based phytomass degradation model to estimate the change in carbon until 1980. Richards and Flint (1994) had estimated the Indian forest area in 1880 as 102.7 Mha. In India, the human population has increased six-fold - from 200 to 1200 million, coupled with economic growth, which has resulted in land use and land cover (LULC) changes during 1880-2010 (Tian et al. 2014). The study has reconstructed the LULC datasets during 1880-2010, using contemporary high-resolution remote sensing datasets from Advanced Wide Field Sensor of Resourcesat 1 (AWiFS) and the historical archives available at district $(\mathrm{N}=590)$ and state $(\mathrm{N}=30)$ levels in India (Tian et al. 2014). The study by Tian et al. (2014) collected the state level LULC datasets for three time periods, including 1880, 1920, and 1950. In order to make the LULC classification from Richards and Flint (1994) similar to other LULC datasets, temporary and permanent crops were aggregated and classified as croplands, grasses and shrubland were aggregated and considered under the grasslands/shrublands category, while built-up and forests were used as such from Richards and Flint (1994). The study on long-term monitoring of forests has provided the distribution, changes in forest cover and the rate of deforestation in India during 1930-2013 (Reddy et al. 2016a). The study has estimated the spatial distribution of phytomass carbon density from satellite remote sensing data, historical archives and collateral data from 1930 to 2013 (Reddy et al. 2016b). The Indian Forest Act (1927), failed to address many issues related to conservation of forests. The Supreme Court of India has banned clear-felling in the forests from 1996 onwards, which has resulted in a decreasing trend in deforestation (Rosencranz and Lele 2008).
The causative factors of deforestation in India were summarised by Reddy et al. (2013).

Continuous monitoring at a national scale permits identification of areas experiencing high degrees of deforestation, which require further analyses at finer spatial resolutions (Ingram and Dawson 2005). The natural forest definition is important for the conservation policies and UNFCCC REDD+ negotiations (Ravindranath et al. 2014). The natural forest is defined as land spanning more than 1 ha, dominated with native tree species having a minimum stand height of $5 \mathrm{~m}$ with an overstorey canopy cover greater than $10 \%$ (Reddy et al. 2016a). Protected areas have long been viewed as key areas for biodiversity conservation and their role is recognised in a globally agreed target to be achieved by 2020 (Clark et al. 2013). But spatial data on the conservation effectiveness of Protected Areas is scarce and must be available for planning. The National Remote Sensing Centre has generated a spatial database for Indian forests over a period of eight decades (Reddy et al. 2016a, b). Jha and Bawa (2006) have quantified the effect of human population growth, human development index (HDI) and deforestation rate and found that when population growth was high, and HDI was low, there was a high rate of deforestation, but when HDI was high, the rate of deforestation was low, and population growth was still high. These results support the observation of low deforestation in the Western Ghats of Kerala, Karnataka, Goa, Maharashtra and Tamil Nadu in the recent past. Deforestation rate decreased in India which shows a population growth of $1.92 \%$ per year and human development index was 0.69 (Jha and Bawa 2006). The development of spatial models offers potential benefits in forest conservation to provide a better understanding on how driving factors govern deforestation, to generate future scenarios of deforestation rates, to predict the locations of forest clearing and to support the design of policy responses to deforestation (Lambin 1994). The models of space simulation based on remote sensing data will introduce a new way of understanding the dynamic processes in geographical space.

Spatial models of land cover change require information on the rate of change and where the change will take place, i.e., both, rate and location. Markov chain model does not consider the driver data in change prediction. Markov chain model only gives the temporal dynamics, not the spatial. As compared to Markov chain model, the Cellular Automata (CA) model has a spatial component, wherein future change is predicted by certain rules from the neighbouring cells. In CA, the state of each cell depends on the spatial and temporal state of its neighbours. CA-Markov is a combination 
of two models, the Cellular Automata model and the Markov model. The temporal and spatial pattern of LULC change can be simulated in the CAMarkov model. CA-Markov improves the accuracy of LULC prediction because it considers the driver data (Choudhari 2013). Spatial models for prediction compute a 'deforestation trend' by comparing land cover maps at two different dates and generating a transition potential map (per-pixel probabilities of shifting from a forest to a non-forest state or vice versa). This is the approach to model and forecast deforestation in CLUE-S, Dinamica EGO, GEOMOD and Land Change Modeler (Vieilledent et al. 2013). Land Change Modeler (LCM), Cellular Automata (CA), Markov Chain, CA-Markov, GEOMOD and STCHOICE are the commonly used modelling techniques (Eastman 2006). Mas et al. (2014) have reviewed the approaches and software used for modelling land use/cover changes. The LCM developed by IDRISI for analysing land cover changes for ecological sustainability, is the most widely used spatial model for prediction.

This study aims to present spatio-temporal patterns of distribution of forest cover and deforestation in India based on remote sensing data and modelling through the Artificial Neural Networks of LCM.

\section{Materials and methods}

\subsection{Data source}

The present study has used spatial layers of multi-temporal classified data of forest cover developed as part of the National Carbon Project by the National Remote Sensing Centre (Reddy et al. 2016a, b).

\subsection{Modelling of the forest cover}

Forest cover for the period 1880 was predicted for entire India. In order to forecast forest cover for 2025, states/union territories of India have been considered based on a significant rate of forest cover change from 2005 to 2013. Six states of Northeast India (Assam, Manipur, Meghalaya, Mizoram, Nagaland, Tripura) and one union territory (Andaman \& Nicobar Islands) had undergone large changes indicating $>0.3$ annual gross rates of deforestation between 2005 and 2013 and was thus selected for further prediction of forest losses. All input spatial data sets were resampled at $56 \mathrm{~m}$ resolution. In this study, forest cover maps were utilised to analyse the transition and modelling. Spatial and temporal observations of the past forest cover change based on historical archives and remote sensing datasets were included in forecasting past forest cover (i.e., change in land cover from nonforest to forest) and deforestation (i.e., change in land cover from forest to non-forest).

LCM was used to analyse the forest cover changes during the periods 1930-1975 and 20052013 to predict the forest covers of the years 1880 and 2025, respectively. The basic principle behind this module is to evaluate the trend of change and the influencing factors. In LCM, there are two options of modelling algorithms that are used to model these selected transition variables. These are logistic regression and multi-layer perceptron neural network (https://clarklabs.org/terrset/land-change-modeler/). A multi-layer perceptron is a powerful system, capable of modelling complex relationships between variables. It allows prediction of an output object for a given input object or a set of input objects. The Markov chain determines the amount of change using the earlier and later land cover maps along with the period specified. The procedure determines exactly how much land would be expected to transition from later date to the predicted date based on a projection of the transition potentials into the future and then creates a transition probabilities file. The transition probabilities file is a matrix that records the probability that each land cover category will change to every other category. In a transition probability matrix, the transition probabilities express the likelihood that a pixel of a given class will change to any other class (or stay the same) in the next period of analysis. A multi-layer perceptron was trained in order to estimate the inclination to deforestation as a function of the explanatory variables and was used to develop deforestation risk assessment maps (Mas et al. 2014).

In this study, current forest to non-forest and non-forest to forest transitions were considered for the computation of the transition potential maps. The probability of deforestation at the pixel level was modelled using elevation (in $\mathrm{m}$ ), slope (in degrees), the shortest distance to roads (in $\mathrm{m}$ ), the shortest distance to nearest settlements (in $\mathrm{m}$ ) and the distance from water bodies. The topographic data from the Shuttle Radar Topography Mission (SRTM) were used. Following the computation of transition potential maps, we calculated transition probabilities for 1930-1975, 1995-2005 and 2005-2013 using the Markov chains. Transition matrices were constructed from the cross tabulation of the forest cover maps. The 19301975 transition probabilities were used as input in the model for 1880-1930, whereas the 2005-2013 transition probabilities were used for 2013-2025. We have simulated forest cover changes under the business-as-usual (BAU) for 1880 and 2025 based on the Markov-cellular automata (MCA) model. 
Table 1. Area statistics for predicted forest cover in 1880 (based on present study) along with other periods (area in $k^{2}{ }^{2}$ ).

\begin{tabular}{|c|c|c|c|c|c|c|c|c|}
\hline Sl. no. & State/UT & 1880 & 1930 & 1975 & 1985 & 1995 & 2005 & 2013 \\
\hline 1 & Andhra Pradesh & 56113 & 44580 & 28282 & 27147 & 26400 & 26017 & 26003 \\
\hline 2 & Arunachal Pradesh & 65323 & 64937 & 59797 & 58933 & 58932 & 58824 & 58822 \\
\hline 3 & Assam & 54106 & 36323 & 23749 & 22479 & 22268 & 21805 & 21250 \\
\hline 4 & Bihar & 8449 & 6983 & 5530 & 5479 & 5457 & 5454 & 5454 \\
\hline 5 & Chhattisgarh & 73619 & 64106 & 59747 & 57588 & 55312 & 55135 & 55116 \\
\hline 6 & Delhi & 78 & 41 & 40 & 34 & 34 & 34 & 34 \\
\hline 7 & Goa & 1976 & 1627 & 1371 & 1292 & 1279 & 1279 & 1279 \\
\hline 8 & Gujarat & 15481 & 14427 & 10825 & 10672 & 10701 & 10698 & 10737 \\
\hline 9 & Haryana & 3827 & 1445 & 876 & 866 & 866 & 866 & 866 \\
\hline 10 & Himachal Pradesh & 22583 & 14762 & 14418 & 14354 & 14354 & 14354 & 14354 \\
\hline 11 & Jammu \& Kashmir & 37627 & 28986 & 18712 & 18679 & 18679 & 18662 & 18662 \\
\hline 12 & Jharkhand & 36111 & 29372 & 23857 & 23358 & 23060 & 22766 & 22766 \\
\hline 13 & Karnataka & 71470 & 53592 & 34511 & 33942 & 33857 & 33781 & 33750 \\
\hline 14 & Kerala & 36296 & 30161 & 11267 & 11029 & 10483 & 10465 & 10462 \\
\hline 15 & Madhya Pradesh & 103072 & 93857 & 79046 & 78550 & 78011 & 77601 & 77590 \\
\hline 16 & Maharashtra & 93935 & 67117 & 50717 & 50563 & 50229 & 50225 & 50213 \\
\hline 17 & Manipur & 18549 & 18465 & 16581 & 15378 & 15434 & 15308 & 15246 \\
\hline 18 & Meghalaya & 16368 & 15891 & 16047 & 16112 & 16279 & 15953 & 15691 \\
\hline 19 & Mizoram & 20277 & 20253 & 17915 & 17870 & 17905 & 17827 & 17768 \\
\hline 20 & Nagaland & 15578 & 14676 & 12806 & 12162 & 12375 & 12464 & 12333 \\
\hline 21 & Odisha & 90907 & 78855 & 55084 & 51648 & 49436 & 48910 & 48757 \\
\hline 22 & Punjab & 3953 & 1913 & 1312 & 1286 & 1286 & 1286 & 1286 \\
\hline 23 & Rajasthan & 26836 & 24679 & 16563 & 15716 & 15359 & 15358 & 15358 \\
\hline 24 & Sikkim & 3686 & 2917 & 2819 & 2819 & 2819 & 2819 & 2819 \\
\hline 25 & Tamil Nadu & 31486 & 24397 & 21925 & 21885 & 21870 & 21867 & 21861 \\
\hline 26 & Telangana & 44635 & 40746 & 18652 & 18368 & 18006 & 17556 & 17520 \\
\hline 27 & Tripura & 9778 & 9081 & 4852 & 4914 & 4829 & 4775 & 4802 \\
\hline 28 & Uttar Pradesh & 24523 & 17628 & 10417 & 10416 & 10416 & 10413 & 10415 \\
\hline 29 & Uttarakhand & 31394 & 24729 & 19604 & 19291 & 19291 & 19291 & 19292 \\
\hline 30 & West Bengal & 16120 & 14670 & 8580 & 8541 & 8509 & 8524 & 8524 \\
\hline 31 & Andaman \& Nicobar & 7585 & 7530 & 7090 & 6970 & 6940 & 6797 & 6416 \\
\hline 32 & Chandigarh & 6 & 6 & 6 & 6 & 6 & 6 & 6 \\
\hline 33 & Dadra \& Nagar Haveli & 251 & 249 & 218 & 109 & 109 & 109 & 109 \\
\hline 34 & Daman \& Diu & 2 & 2 & 2 & 2 & 2 & 2 & 2 \\
\hline 35 & Lakshadweep & 0 & 0 & 0 & 0 & 0 & 0 & 0 \\
\hline Total & & 1042008 & 869012 & 653220 & 638460 & 630795 & 627233 & 625565 \\
\hline
\end{tabular}

Source: 1880 (present study) and 1930, 1975, 1985, 1995, 2005 and 2013 (Reddy et al. 2016a, b).

The BAU scenario assumed that historical forest cover changes observed between 2013 and 2025 under the current socioeconomic conditions would continue in the future. Thus, this scenario used annual transition probabilities between 2005 and 2013, as well as biophysical factors such as slope and elevation, distance to water bodies, distance to major roads and distance to settlements, in order to compute transition potential maps. The model was set to run from 1995 (the initial year of simulation) to 2005 , which is the year of the actual (observed) forest cover map to get 2013. The simulated forest cover map (2013) was compared to the actual forest cover map (2013), in order to validate the accuracy of the model. For prediction of the past forest cover, we have compared with the estimate of Richards and Flint (1994), which is based on non-spatial historical records and population and degradation model. The inventory information of land use/land cover (LULC) datasets in the tabular forms are inadequate for the use in climatic, ecological, hydrological and biogeochemical 


\section{Change Analysis}

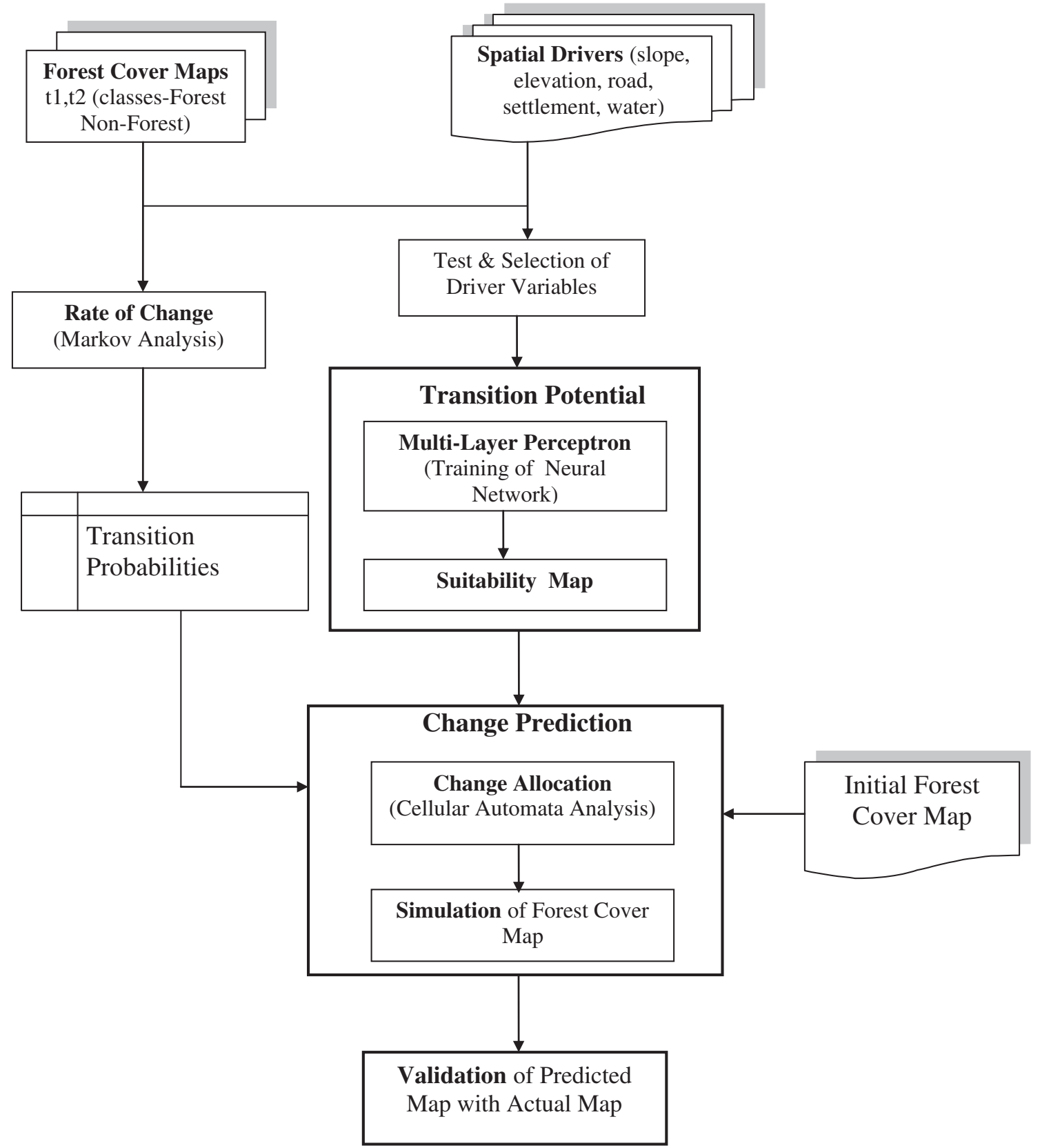

Figure 1. Flowchart of the general procedure used in forest cover change modelling.

models that require LULC in the gridded format (Tian et al. 2014).

\subsection{Rate of deforestation}

Forest area loss can be measured using spatial analysis. The annual rate of forest cover change is calculated by comparing the area under forest cover in the same region at two different times (Puyravaud 2003).

$$
r=\frac{1}{\left(t_{2}-t_{1}\right)} \times \ln \frac{a_{2}}{a_{1}}
$$

where $r$ is the annual rate of change (percentage per year), $a_{1}$ and $a_{2}$ are the forest cover estimates at time $t_{1}$ and $t_{2}$, respectively.

\subsection{Forest cover change modelling}

This study has modelled forest cover change using the forest cover maps of two consecutive time periods. IDRISI Selva software was used to estimate probabilities of pixels changing from forest to non-forest and non-forest to forest using Markov techniques (https://clarklabs.org/terrset/ 
Table 2. Net rate of deforestation in States/Union Territories of India: 1880-2013.

\begin{tabular}{|c|c|c|c|c|c|c|c|}
\hline Sl. no. & State/UT & 1880-1930 & 1930-1975 & 1975-1985 & 1985-1995 & $1995-2005$ & $2005-2013$ \\
\hline 1 & Andhra Pradesh & 0.46 & 1.01 & 0.41 & 0.28 & 0.15 & 0.01 \\
\hline 2 & Arunachal Pradesh & 0.01 & 0.18 & 0.15 & 0.00 & 0.02 & 0.00 \\
\hline 3 & Assam & 0.80 & 0.94 & 0.55 & 0.09 & 0.21 & 0.32 \\
\hline 4 & Bihar & 0.38 & 0.52 & 0.09 & 0.04 & 0.01 & 0.00 \\
\hline 5 & Chhattisgarh & 0.28 & 0.16 & 0.37 & 0.40 & 0.03 & 0.00 \\
\hline 6 & Delhi & 1.29 & 0.05 & 1.63 & 0.00 & 0.00 & 0.00 \\
\hline 7 & Goa & 0.39 & 0.38 & 0.59 & 0.10 & 0.00 & 0.00 \\
\hline 8 & Gujarat & 0.14 & 0.64 & 0.14 & 0.00 & 0.00 & 0.00 \\
\hline 9 & Haryana & 1.95 & 1.11 & 0.10 & 0.00 & 0.00 & 0.00 \\
\hline 10 & Himachal Pradesh & 0.85 & 0.05 & 0.04 & 0.00 & 0.00 & 0.00 \\
\hline 11 & Jammu \& Kashmir & 0.52 & 0.97 & 0.02 & 0.00 & 0.01 & 0.00 \\
\hline 12 & Jharkhand & 0.41 & 0.46 & 0.21 & 0.13 & 0.13 & 0.00 \\
\hline 13 & Karnataka & 0.58 & 0.98 & 0.17 & 0.03 & 0.02 & 0.01 \\
\hline 14 & Kerala & 0.37 & 2.19 & 0.21 & 0.51 & 0.02 & 0.00 \\
\hline 15 & Madhya Pradesh & 0.19 & 0.38 & 0.06 & 0.07 & 0.05 & 0.00 \\
\hline 16 & Maharashtra & 0.67 & 0.62 & 0.03 & 0.07 & 0.00 & 0.00 \\
\hline 17 & Manipur & 0.01 & 0.24 & 0.75 & 0.00 & 0.08 & 0.05 \\
\hline 18 & Meghalaya & 0.06 & 0.00 & 0.00 & 0.00 & 0.20 & 0.21 \\
\hline 19 & Mizoram & 0.00 & 0.27 & 0.03 & 0.00 & 0.04 & 0.04 \\
\hline 20 & Nagaland & 0.12 & 0.30 & 0.52 & 0.00 & 0.00 & 0.13 \\
\hline 21 & Odisha & 0.28 & 0.80 & 0.64 & 0.44 & 0.11 & 0.04 \\
\hline 22 & Punjab & 1.45 & 0.84 & 0.20 & 0.00 & 0.00 & 0.00 \\
\hline 23 & Rajasthan & 0.17 & 0.89 & 0.52 & 0.23 & 0.00 & 0.00 \\
\hline 24 & Sikkim & 0.47 & 0.08 & 0.00 & 0.00 & 0.00 & 0.00 \\
\hline 25 & Tamil Nadu & 0.51 & 0.24 & 0.02 & 0.01 & 0.00 & 0.00 \\
\hline 26 & Telangana & 0.18 & 1.74 & 0.15 & 0.20 & 0.25 & 0.03 \\
\hline 27 & Tripura & 0.15 & 1.39 & 0.00 & 0.17 & 0.11 & 0.00 \\
\hline 28 & Uttar Pradesh & 0.66 & 1.17 & 0.00 & 0.00 & 0.00 & 0.00 \\
\hline 29 & Uttarakhand & 0.48 & 0.52 & 0.16 & 0.00 & 0.00 & 0.00 \\
\hline 30 & West Bengal & 0.19 & 1.19 & 0.05 & 0.04 & 0.00 & 0.00 \\
\hline 31 & Andaman \& Nicobar & 0.01 & 0.40 & 0.17 & 0.04 & 0.21 & 0.72 \\
\hline 32 & Chandigarh & 0.00 & 0.00 & 0.00 & 0.00 & 0.00 & 0.00 \\
\hline 33 & Dadra \& Nagar Haveli & 0.02 & 0.30 & 6.93 & 0.00 & 0.00 & 0.00 \\
\hline 34 & Daman \& Diu & 0.00 & 0.00 & 0.00 & 0.00 & 0.00 & 0.00 \\
\hline 35 & Lakshadweep & 0.00 & 0.00 & 0.00 & 0.00 & 0.00 & 0.00 \\
\hline 36 & Puducherry & 0.00 & 3.34 & 0.00 & 0.00 & 0.00 & 0.00 \\
\hline
\end{tabular}

Source: 1880-1930 (present study) and 1930-1975, 1975-1985, 1985-1995, 2005-2013 (Reddy et al. 2016a, b).

land-change-modeler/). The model was developed by analysing the change in forest cover between 1995 and 2005 and computing the probability of each cell undergoing change by deforestation. The success was measured by validating the model (generated using various drivers with the LCM) for the year 2013 with a classified image of the actual forest cover map in 2013.

\subsubsection{Change detection analysis using LCM method}

The change analysis panel provides a rapid assessment of quantitative change by graphing gains and losses by land cover categories. The basic principle behind this module is to evaluate the trend of the change from forest to non-forest and non-forest to forest, the influencing factors such as roads, slope, the elevation and settlement, and finally predict the deforestation/afforestation pattern based on the previous change trend.

\subsubsection{Transition potentials modelling with LCM}

The main goal is to create transition potential maps or simply a suitability map with an acceptable degree of accuracy to run the actual 


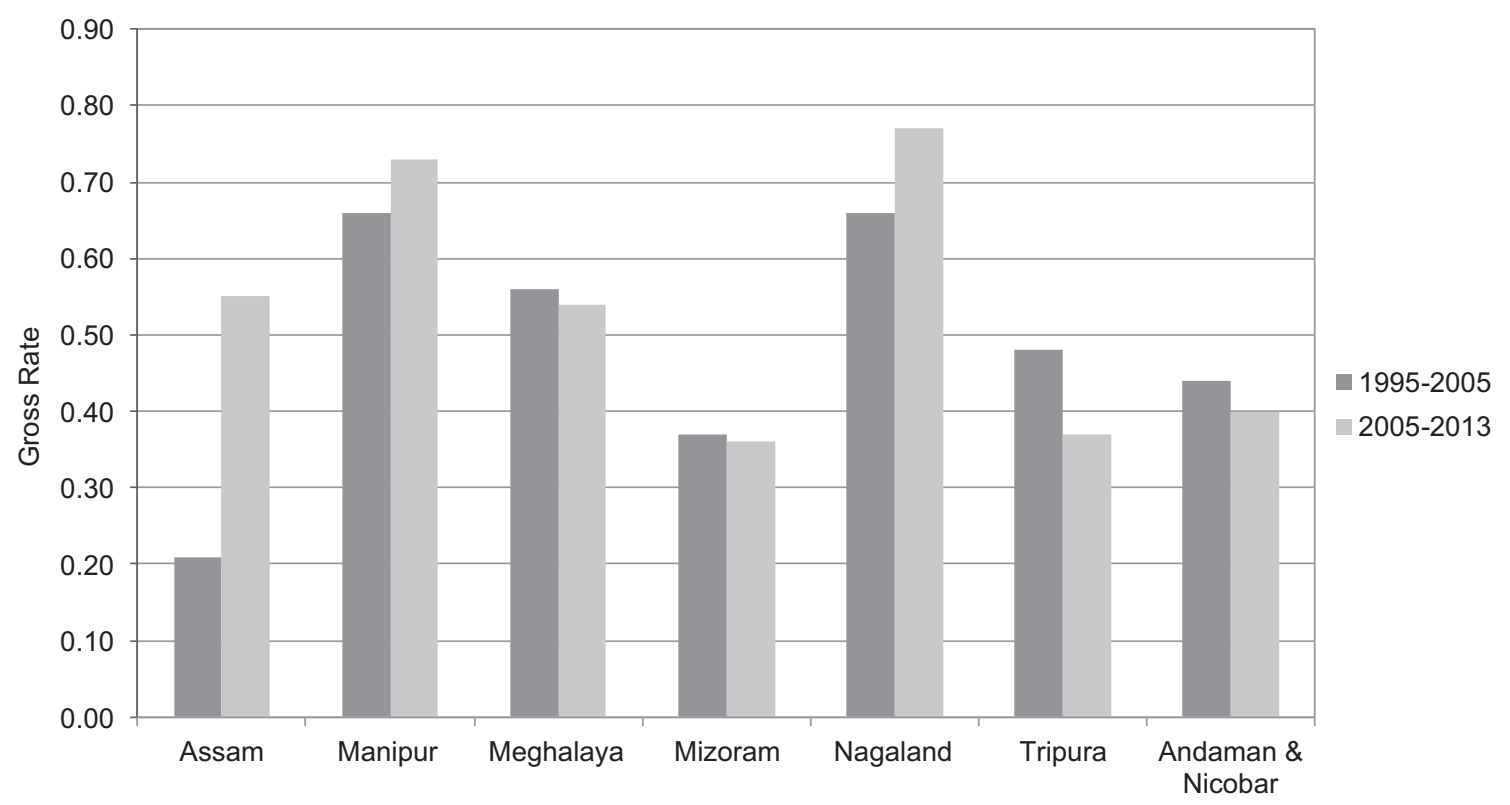

Figure 2. Percentage annual gross rate of deforestation in India (1995-2013).

Table 3. Gross rate of deforestation in selected states/UTs of India (1995-2005 and 2005-2013).

\begin{tabular}{lcc}
\hline State/UT & $1995-2005$ & $2005-2013$ \\
\hline Assam & 0.21 & 0.55 \\
Manipur & 0.66 & 0.73 \\
Meghalaya & 0.56 & 0.54 \\
Mizoram & 0.37 & 0.36 \\
Nagaland & 0.66 & 0.77 \\
Tripura & 0.48 & 0.37 \\
Andaman \& Nicobar & 0.44 & 0.40 \\
\hline
\end{tabular}

modelling. Hence, the transition potentials tab allows us to group transitions into a set of submodels and explore the potential power of explanatory variables. This procedure of identifying and selecting relevant variables plays an important role in reducing excessive model complexity, which improves the overall modelling performances (Mas et al. 2014).

\subsubsection{Transition submodel status}

This step provides the list of all minor to major transitions that has occurred from time $t_{1}$ to time $t_{2}$. Summary analysis has been done to verify the explanatory power of the variables. The selected transition is collected into a submodel. The multi-layer perceptron (MLP) neural network was selected to model the forest to non-forest land cover transition potential and to create a layer, expressing for each pixel the probability of changing within a specific time structure.
Table 4. Net rate and gross rate of deforestation in selected states/UTs of India from 2013 to 2025 (area in $\mathrm{km}^{2}$ ).

\begin{tabular}{lrrcc}
\hline State/UT & 2013 & 2025 & Net rate & Gross rate \\
\hline Assam & 21250 & 19966 & 0.52 & 0.54 \\
Manipur & 15246 & 14893 & 0.2 & 0.90 \\
Meghalaya & 15691 & 15321 & 0.2 & 0.49 \\
Mizoram & 17768 & 17717 & 0.02 & 0.48 \\
Nagaland & 12333 & 12293 & 0.03 & 1.24 \\
Tripura & 4802 & 4842 & 0 & 0.54 \\
Andaman \& Nicobar & 6416 & 6169 & 0.33 & 0.72 \\
Total & 93506 & 91201 & 0.65 & 0.74 \\
\hline
\end{tabular}

\subsubsection{Major spatial factors for evaluation of drivers of forest cover change}

This work has analysed explanatory variables linked to forest cover change and to model the change using MLP neural network. Transition potentials are expressed as the likelihood of one land cover category changing to another. The MLP neural network approach was used to create transition potential maps. Five major drivers were identified and assessed for correlation to forest cover change. Variables can be added to the model either as static or dynamic components (Eastman 2006). Static variables express aspects of basic suitability for the transition under consideration and are unchanging over time. The explanatory variables used to understand forest cover change are slope and elevation classes and three distance variables, i.e., distance from roads, settlements and water bodies. Slope and elevation classes are considered as major explanatory variables generated using SRTM DEM. Dynamic variables are 


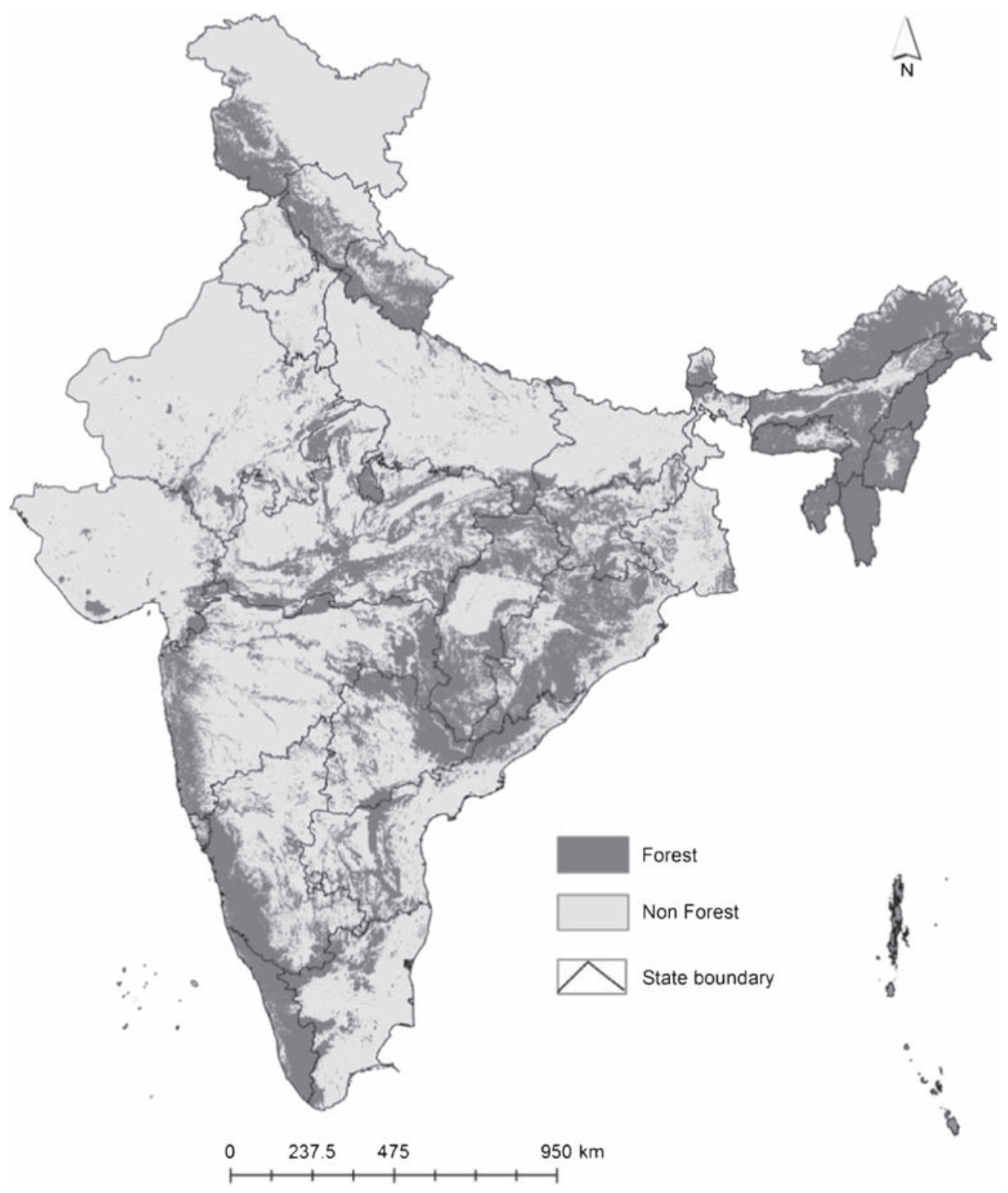

Figure 3. Predicted forest cover map of India: 1880.

time-dependent drivers such as proximity to existing development or infrastructure and are recalculated over time during the course of a prediction. Elevation and slope are static explanatory variables in transition sub-model structure, whereas, distance from the road, settlement and water bodies are dynamic variables.

LCM's test and selection of site and driver variable module were used to test the potential power of explanatory variables (table 1 ). The driver variable test procedure is based on a contingency table analysis. For qualitative variables, it uses the native categories of the variable to test association with the distribution of forest and non-forest in the later forest map. Quantitative variables are binned to 256 categories in order to conduct this test. The quantitative measure of association used is Cramer's V. Cramer's V is a statistic that transforms chi-square (for a contingency table larger than two rows $\times$ two columns) to a range of $0-1$, where a unit value indicates complete agreement between the two nominal variables (Liebetrau 1983). A high Cramer's V indicates that the potential explanatory value of the variable is good. However, it is a good indication that a variable can be discarded if the Cramer's V is low. Only variables with values higher than 0.15 were kept in the submodel structure. The p-value expresses the probability that the Cramer's V is not significantly different from 0 . A high value of ' $p$ ' is a sure sign that it can be rejected.

\subsubsection{Change prediction}

The change prediction provides the controls for a dynamic forest cover change prediction process. 

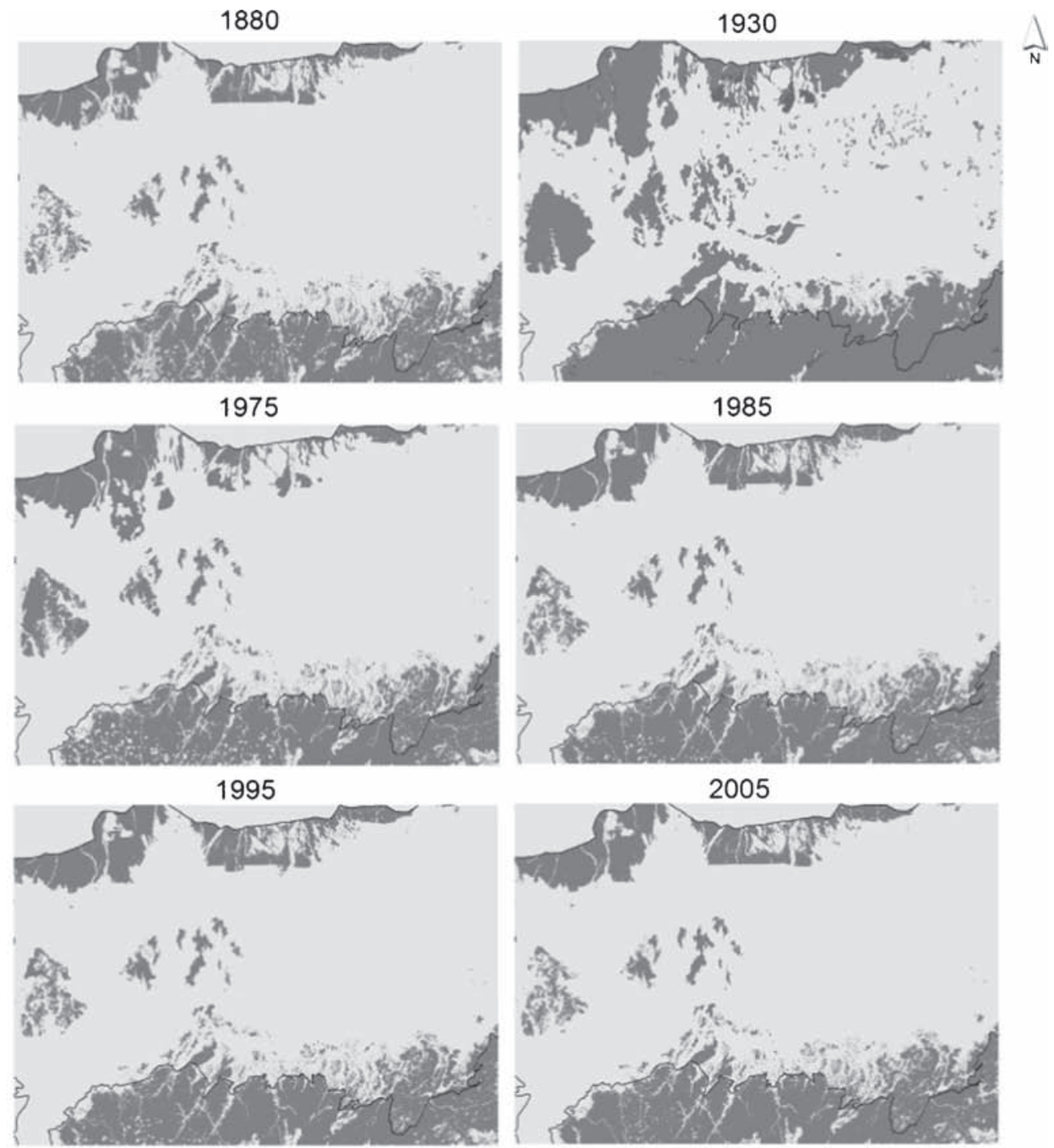

2013
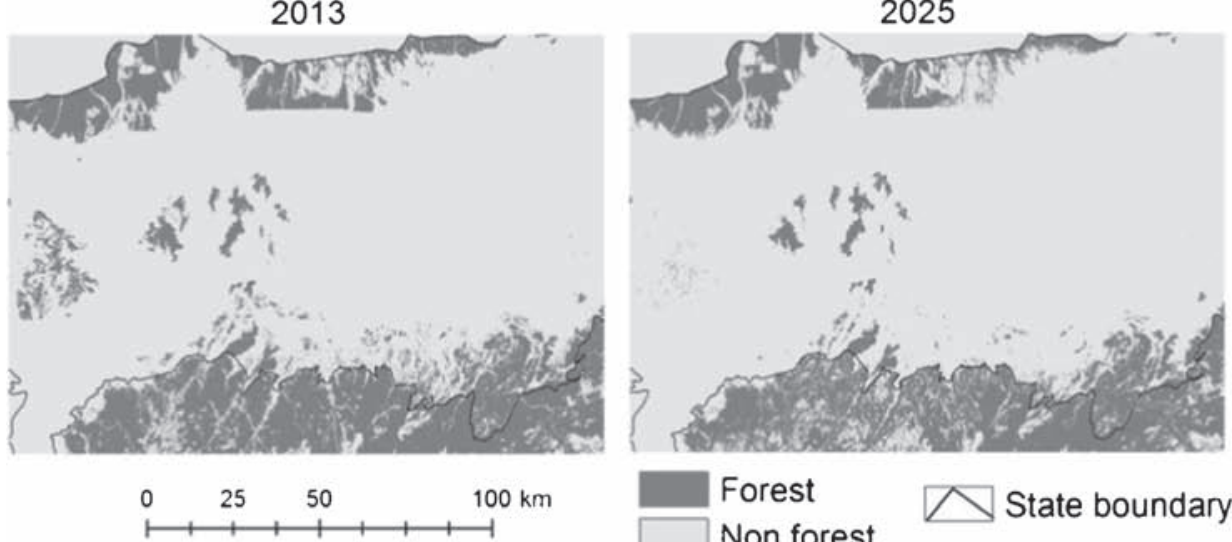

Forest Non forest

Figure 4. Mapped and predicted forest cover in parts of Assam and Meghalaya: 1880-2025.

Using the transition potential maps created in the Transition Potentials tab, the quantity of change in each transition can be modelled. In its simplest form, the model will determine how the variables influence future change, how much change took place between time 1 and time 2 , and then calculate a relative amount of transition to the future date.

\subsubsection{Model performance in forecasting deforestation}

The accuracy was measured by validating the predicted maps (generated using various drivers with the LCM) for the year 2013 with a classified image of actual forest cover map in 2013. We computed a confusion table comparing the 

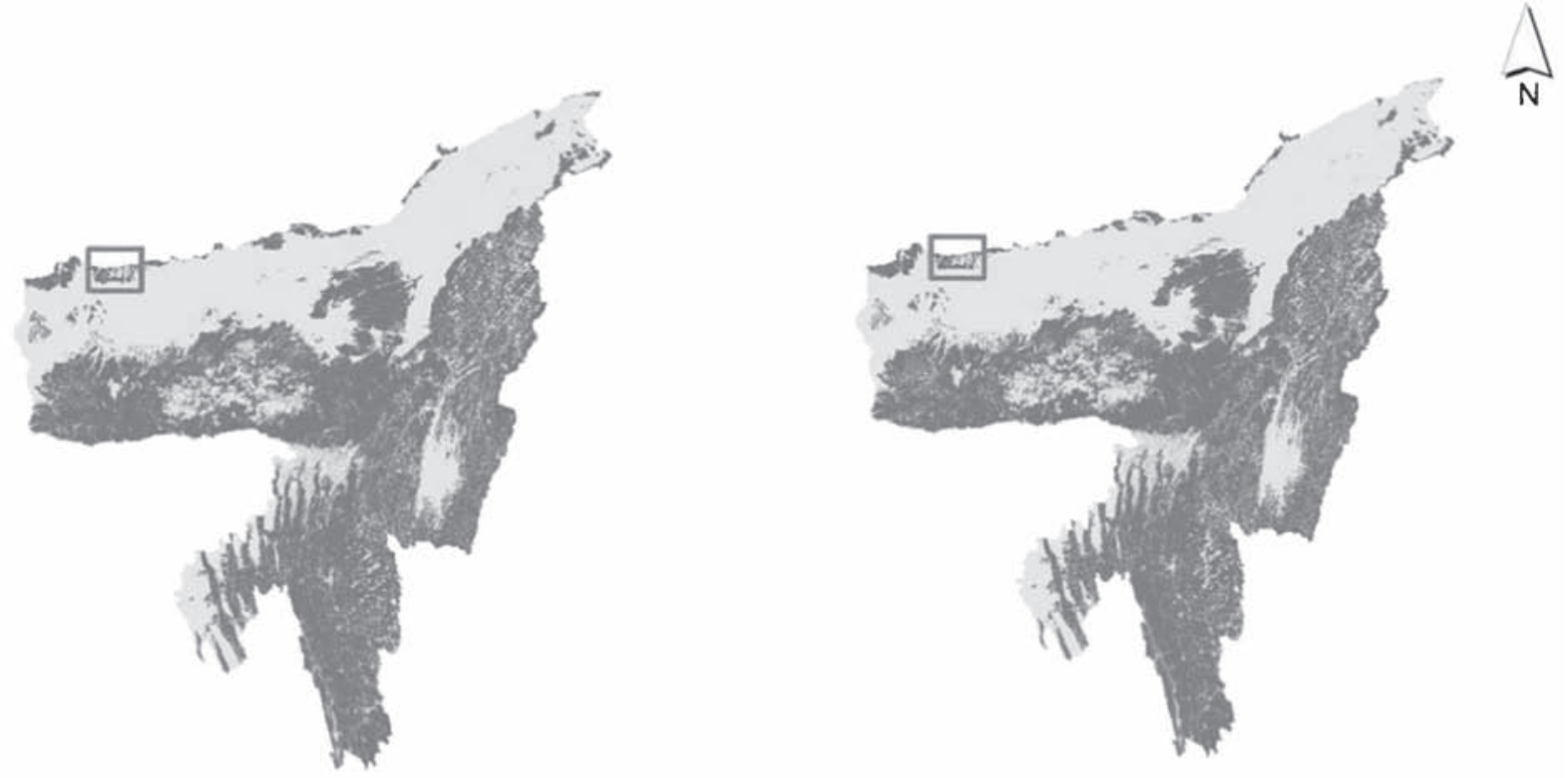

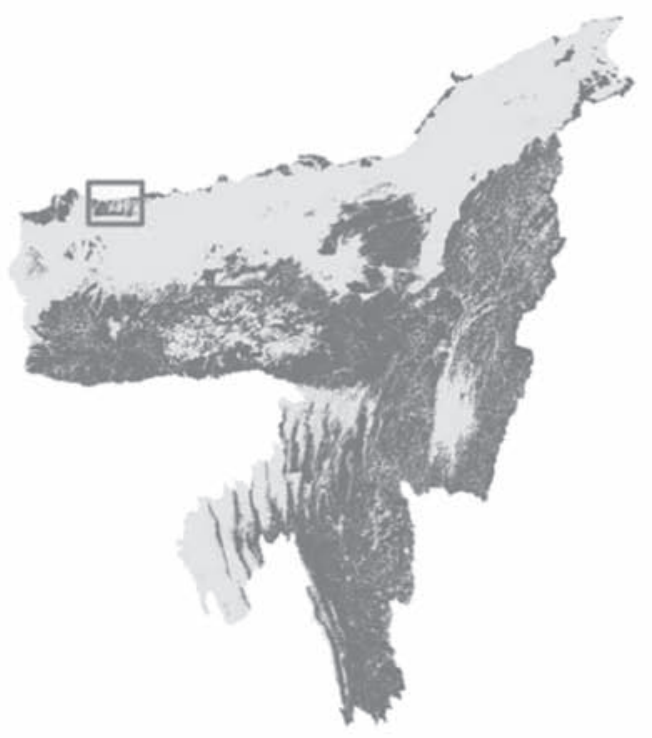

1995

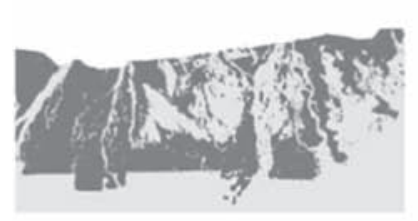

2005

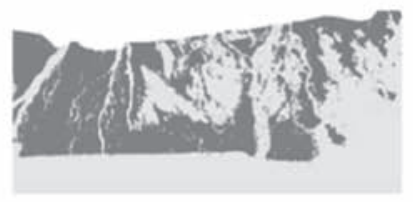

0

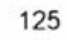

125

$500 \mathrm{~km}$

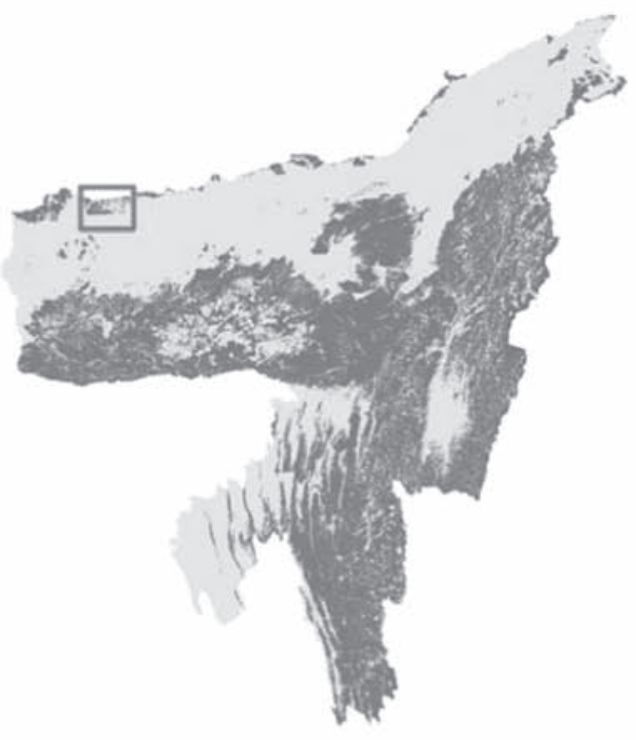

2013

2025
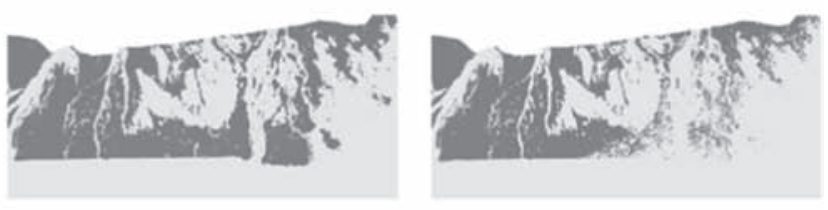

Forest

Non-Forest

Figure 5. Forest cover maps of the Northeast: 1995 to 2025.

predictions of our modelling approach with the actual observations of the forest. Cohen's Kappa was computed from the confusion table. Cohen's Kappa coefficient is a statistic which measures inter-rater agreement for qualitative items. The
Kappa statistic (or value) is a metric that compares an observed accuracy with an expected accuracy (random chance). Computation of observed accuracy and expected accuracy is integral to the comprehension of the kappa statistic and is most 

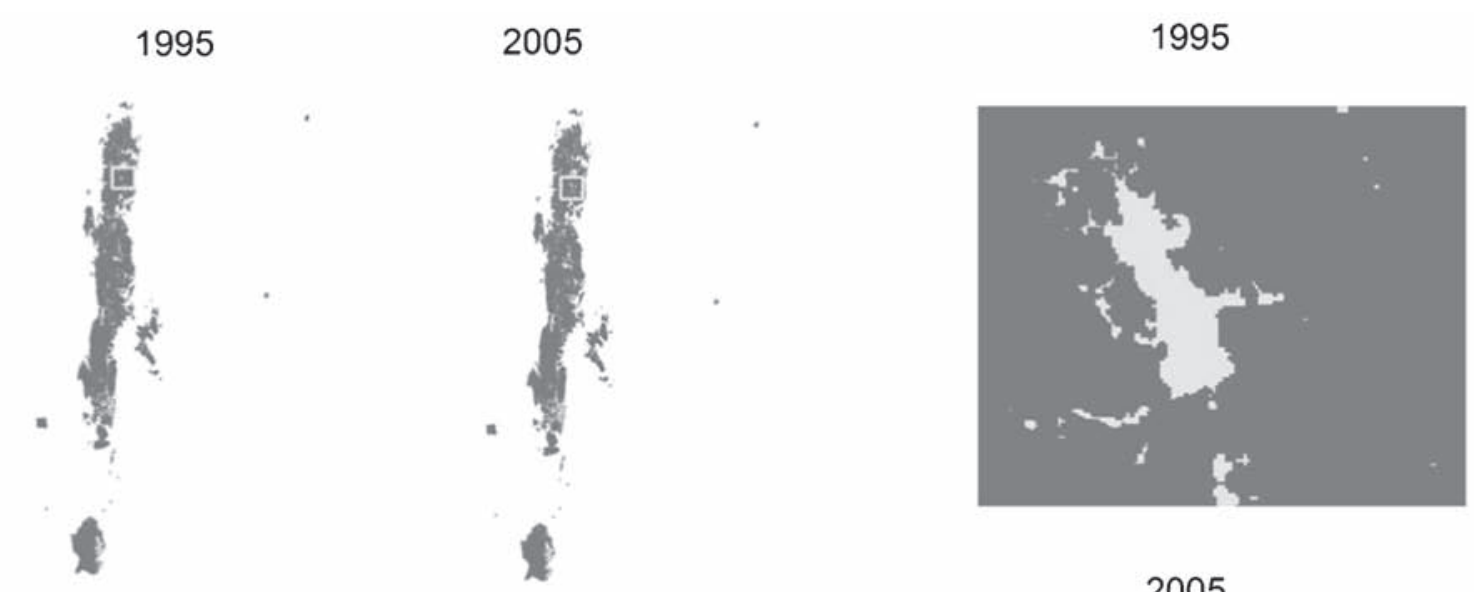

$\bigwedge_{N}$
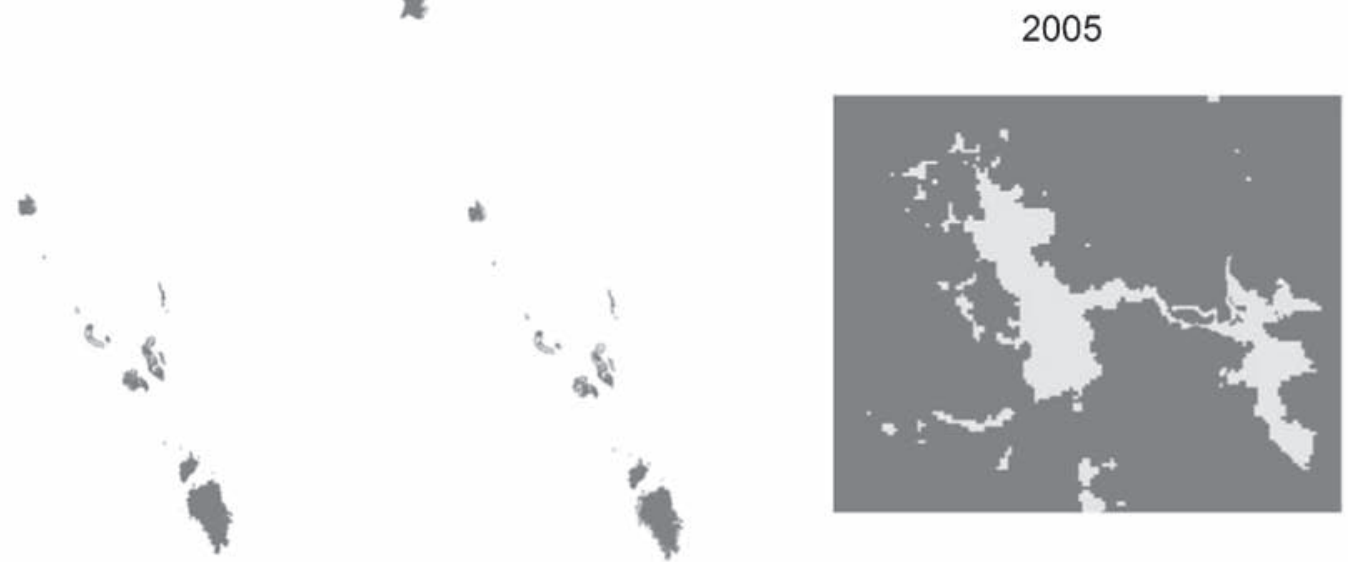

2013

2013
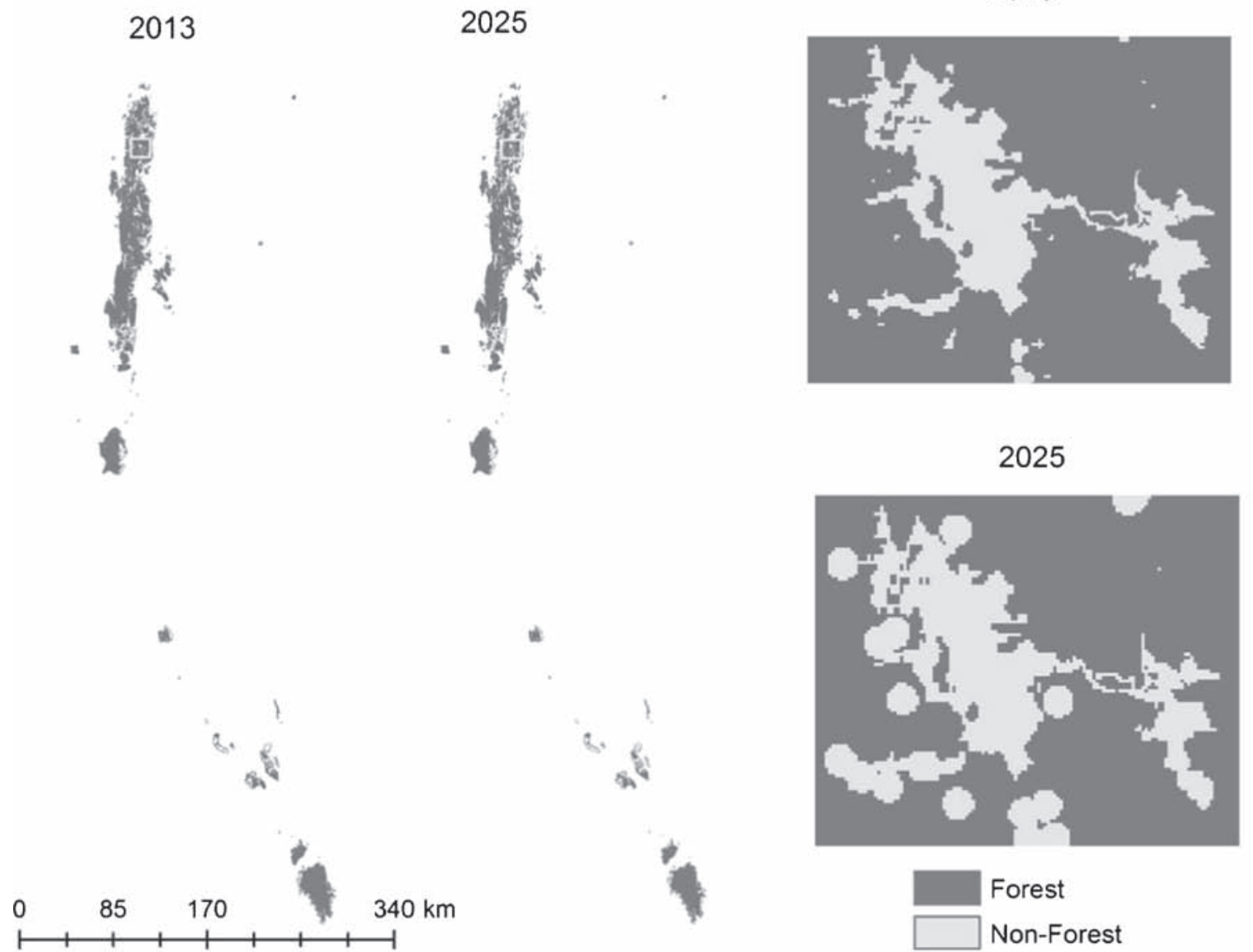

Figure 6. Forest cover maps of Andaman \& Nicobar Islands: 1995-2025. 


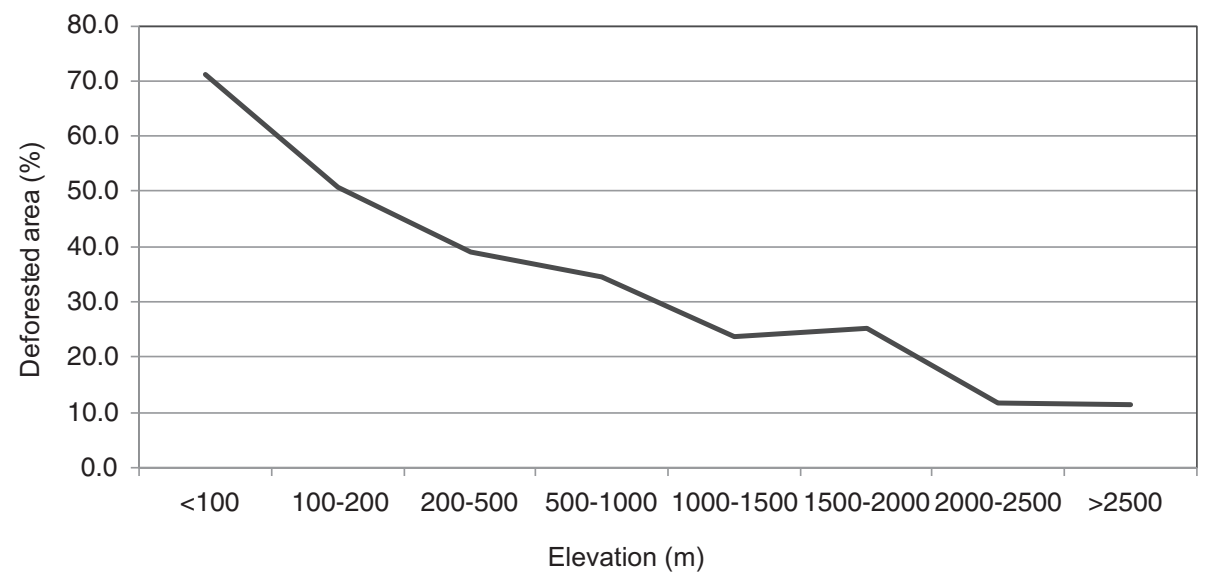

Figure 7. Elevation-wise representation of deforested area from 1880 to 2013 (area in $\mathrm{km}^{2}$ ).

easily illustrated through the use of a confusion matrix.

Observed accuracy is simply the number of instances that were classified correctly throughout the entire confusion matrix.

Expected accuracy is defined as the accuracy that any random classifier would be expected to achieve based on the confusion matrix.

$$
\text { Kappa }=\frac{\text { (observed accuracy }- \text { expected accuracy })}{(1-\text { expected accuracy })}
$$

Flow chart of the methodology is given in figure 1.

\section{Results and discussion}

\subsection{Analysis of forest cover changes}

Forest cover change analyses revealed a high rate of changes between 1880 and 1930 and a lower rate of changes between 2013 and 2025. Area statistics for predicted forest cover in 1880 indicates an area of $10,042,008 \mathrm{~km}^{2}$ which represents $31.7 \%$ of the geographical area of India (table 1). Richards and Flint (1994) had estimated the Indian forest area in 1880 as 102.7 Mha $\left(10,27,000 \mathrm{~km}^{2}\right)$. However, the study by Richards and Flint (1994) has not provided any spatial map of forest cover for 1880 . The present study based on LCM predicted the forest area to be 10,42,008 $\mathrm{km}^{2}$ (104.2 Mha). The net loss of forest in India is estimated as $416,443 \mathrm{~km}^{2}(40 \%)$ from 1880 to 2013. Percentage net rate of deforestation in states/Union Territories of India for the period of $1880-2013$ is given in table 2 . This study has predicted varying rates of the ever-continuing deforestation for 2025 in the Northeast region and Andaman \& Nicobar Islands.

Analysis of historical forest area change from 1880 to 2013 indicates the highest loss in Maharashtra $\left(43722 \mathrm{~km}^{2}\right)$, followed by Odisha, Karnataka, Assam, Andhra Pradesh, Telangana,
Kerala, Madhya Pradesh, Jammu \& Kashmir and Chhattisgarh. Based on the percentage loss of forest area from 1880 to 2013, Haryana has lost the most forest cover $(77.4 \%)$, followed by Kerala (71.2\%), Punjab (67.5\%), Assam (60.7\%), Telangana (60.7\%), Uttar Pradesh (57.5\%), Andhra Pradesh (53.7\%), Karnataka (52.8\%), Tripura $(50.9 \%)$ and Jammu \& Kashmir (50.4\%). Presently many of the states which have undergone largescale deforestation are successful in minimising forest loss from 1995. Gross rate of deforestation in selected states/UTs of India (1995-2005 and 20052013) is given in figure 2 and table 3. Net and gross rates of deforestation in selected states/UTs of India from 2013 to 2025 is given table 4 .

The predicted forest cover for 2025 indicates areas of $19,966,14,893,15,321,17,717,12,293$, 4842 and $6169 \mathrm{~km}^{2}$ in Assam, Manipur, Meghalaya, Mizoram, Nagaland, Tripura and Andaman \& Nicobar Islands, respectively. The estimation of percentage net rate of deforestation in Assam, Manipur, Meghalaya, Mizoram, Nagaland and Andaman \& Nicobar for 2013-2025 shows 0.52, $0.20,0.02,0.03$ and 0.33 , respectively. Tripura has no net rate of forest loss, but gross forest loss was indicated to be 0.54 during 2013-2025. During the period 2013-2025, $7064 \mathrm{~km}^{2}$ forest cover has been lost and $4759 \mathrm{~km}^{2}$ was regained, with a net change of $2305 \mathrm{~km}^{2}$. Predicted forest cover map of India for 1880 is given in figure 3. Forest cover maps for the selected parts of Northeast India is shown in figure 4. Mapped and predicted forest cover map of Northeast India for 1995-2025 is shown in figure 5. Predicted forest cover map of Andaman \& Nicobar Islands for 1995-2025 is shown in figure 6 .

The study showed an inverse relationship of deforestation with increasing elevation level, as also observed by Reddy et al. (2016a, b) from 1930 to 2013. The present analysis also showed that the low elevation forests with better access are more vulnerable to forest cover change (figure 7); 
Table 5. Areal extent of forest cover in protected areas of the Northeast (area in $\mathrm{km}^{2}$ ).

\begin{tabular}{|c|c|c|c|c|c|c|c|c|c|c|c|}
\hline Sl. no. & Protected area & State & Notification & 1880 & 1930 & 1975 & 1985 & 1995 & 2005 & 2013 & 2025 \\
\hline 1 & Amchang & Assam & 2004 & 74 & 74 & 74 & 74 & 74 & 74 & 74 & 74 \\
\hline 2 & Barail & Assam & 2004 & 344 & 343 & 328 & 328 & 328 & 328 & 327 & 327 \\
\hline 3 & Bherjan-Borajan-Padumoni & Assam & 1999 & 8 & 8 & 1 & 1 & 1 & 1 & 1 & 1 \\
\hline 4 & Burachapori & Assam & 1975 & 37 & 6 & 6 & 6 & 6 & 6 & 5 & 5 \\
\hline 5 & Chakrasila & Assam & 1994 & 46 & 45 & 42 & 42 & 42 & 42 & 42 & 42 \\
\hline 6 & Dibru-Saikhowa & Assam & 1999 & 321 & 358 & 258 & 153 & 153 & 119 & 119 & 119 \\
\hline 7 & Dihing Patkai & Assam & 2004 & 98 & 99 & 93 & 92 & 92 & 92 & 92 & 92 \\
\hline 8 & East Karbi Anglong & Assam & 2000 & 226 & 226 & 215 & 215 & 215 & 215 & 214 & 214 \\
\hline 9 & Garampani & Assam & 1952 & 2 & 2 & 2 & 2 & 1 & 1 & 1 & 1 \\
\hline 10 & Hollongapar Gibbon & Assam & 1997 & 17 & 17 & 17 & 17 & 17 & 17 & 17 & 17 \\
\hline 11 & Kaziranga & Assam & 1974 & 157 & 50 & 82 & 74 & 74 & 74 & 74 & 74 \\
\hline 12 & Lawkhowa & Assam & 1979 & 52 & 16 & 16 & 16 & 16 & 16 & 15 & 16 \\
\hline 13 & Manas & Assam & 1990 & 2069 & 1735 & 1502 & 1454 & 1402 & 1345 & 1236 & 1132 \\
\hline 14 & Marat Longri & Assam & 2003 & 355 & 355 & 325 & 321 & 321 & 319 & 305 & 304 \\
\hline 15 & Nambor & Assam & 2000 & 9 & 9 & 14 & 11 & 11 & 11 & 11 & 11 \\
\hline 16 & Nambor-Doigurung & Assam & 1975 & 55 & 50 & 37 & 41 & 36 & 36 & 36 & 36 \\
\hline 17 & Nameri & Assam & 1998 & 260 & 268 & 305 & 222 & 222 & 169 & 166 & 162 \\
\hline 18 & Orang (Rajiv Gandhi) & Assam & 1999 & 45 & 4 & 4 & 4 & 4 & 4 & 3 & 4 \\
\hline 19 & Pabitora & Assam & 1987 & 33 & 10 & 13 & 13 & 13 & 13 & 12 & 13 \\
\hline 20 & Sonai-Rupai & Assam & 1998 & 192 & 194 & 193 & 173 & 173 & 112 & 99 & 97 \\
\hline 21 & Yangoupokpi-Lokchao & Manipur & 1989 & 178 & 178 & 172 & 147 & 148 & 147 & 146 & 146 \\
\hline 22 & Balphakram & Meghalaya & 1985 & 612 & 599 & 602 & 605 & 601 & 589 & 589 & 589 \\
\hline 23 & Nokrek & Meghalaya & 1986 & 77 & 77 & 73 & 76 & 76 & 75 & 76 & 76 \\
\hline 24 & Nongkhyllem & Meghalaya & 1981 & 59 & 59 & 64 & 64 & 64 & 64 & 64 & 64 \\
\hline 25 & Siju & Meghalaya & 1979 & 64 & 64 & 65 & 66 & 66 & 65 & 66 & 66 \\
\hline 26 & Dampa & Mizoram & 1976 & 277 & 276 & 271 & 275 & 275 & 275 & 275 & 275 \\
\hline 27 & Khawnglung & Mizoram & 1991 & 52 & 51 & 48 & 48 & 49 & 48 & 49 & 47 \\
\hline 28 & Lengteng & Mizoram & 1999 & 59 & 59 & 57 & 57 & 56 & 54 & 54 & 54 \\
\hline 29 & Murlen & Mizoram & 2003 & 88 & 88 & 86 & 83 & 80 & 79 & 79 & 79 \\
\hline 30 & Ngengpui & Mizoram & 1991 & 77 & 77 & 74 & 75 & 75 & 75 & 75 & 75 \\
\hline 31 & Phawngpui Blue Mountain & Mizoram & 1997 & 38 & 38 & 38 & 37 & 37 & 37 & 35 & 37 \\
\hline 32 & Pualreng & Mizoram & 2004 & 45 & 45 & 41 & 44 & 44 & 45 & 44 & 44 \\
\hline 33 & Tawi & Mizoram & 1978 & 32 & 32 & 30 & 31 & 31 & 31 & 31 & 31 \\
\hline 34 & Thorangtlang & Mizoram & 2001 & 66 & 66 & 65 & 66 & 66 & 66 & 66 & 66 \\
\hline 35 & Tokalo & Mizoram & 2007 & 59 & 59 & 56 & 57 & 57 & 57 & 57 & 57 \\
\hline 36 & Fakim & Nagaland & 1984 & 7 & 7 & 7 & 7 & 7 & 7 & 7 & 7 \\
\hline 37 & Intanki & Nagaland & 1993 & 244 & 243 & 234 & 226 & 226 & 219 & 220 & 220 \\
\hline 38 & Puliebadze & Nagaland & 1980 & 10 & 10 & 9 & 9 & 9 & 10 & 9 & 9 \\
\hline 39 & Bison (Rajbari) & Tripura & 2007 & 1 & 1 & 1 & 1 & 1 & 1 & 1 & 1 \\
\hline 40 & Clouded Leopard & Tripura & 2007 & 4 & 4 & 3 & 3 & 3 & 3 & 2 & 3 \\
\hline 41 & Gumti & Tripura & 1987 & 358 & 373 & 307 & 299 & 291 & 284 & 291 & 291 \\
\hline 42 & Sepahijala & Tripura & 1987 & 13 & 12 & 7 & 6 & 6 & 6 & 6 & 6 \\
\hline \multirow[t]{2}{*}{43} & Trishna & Tripura & 1988 & 209 & 206 & 76 & 72 & 72 & 71 & 71 & 71 \\
\hline & & & & 7029 & 6493 & 5912 & 5611 & 5538 & 5304 & 5164 & 5057 \\
\hline
\end{tabular}

a similar result was also reported by Reddy et al. (2016a, b).

Deforestation rate was relatively greater under the British rule (1880-1947) and early decades after independence and then decreased after the 1980s due to the formulation of government policies to conserve forests (Tian et al. 2014). Among the different parts of India, Andaman \& Nicobar
Islands, Assam, Meghalaya, Mizoram, Nagaland and Manipur are undergoing a high rate of gross deforestation. According to long-term study on deforestation (1930-2013), the highest forest loss was recorded in Kerala (65.3\%), followed by Telangana (57\%), Tripura (47.1\%), West Bengal (41.9\%), Assam (41.5\%), Uttar Pradesh (40.9\%), Haryana (40.1\%) and Odisha (38.2\%) (Reddy et al. 


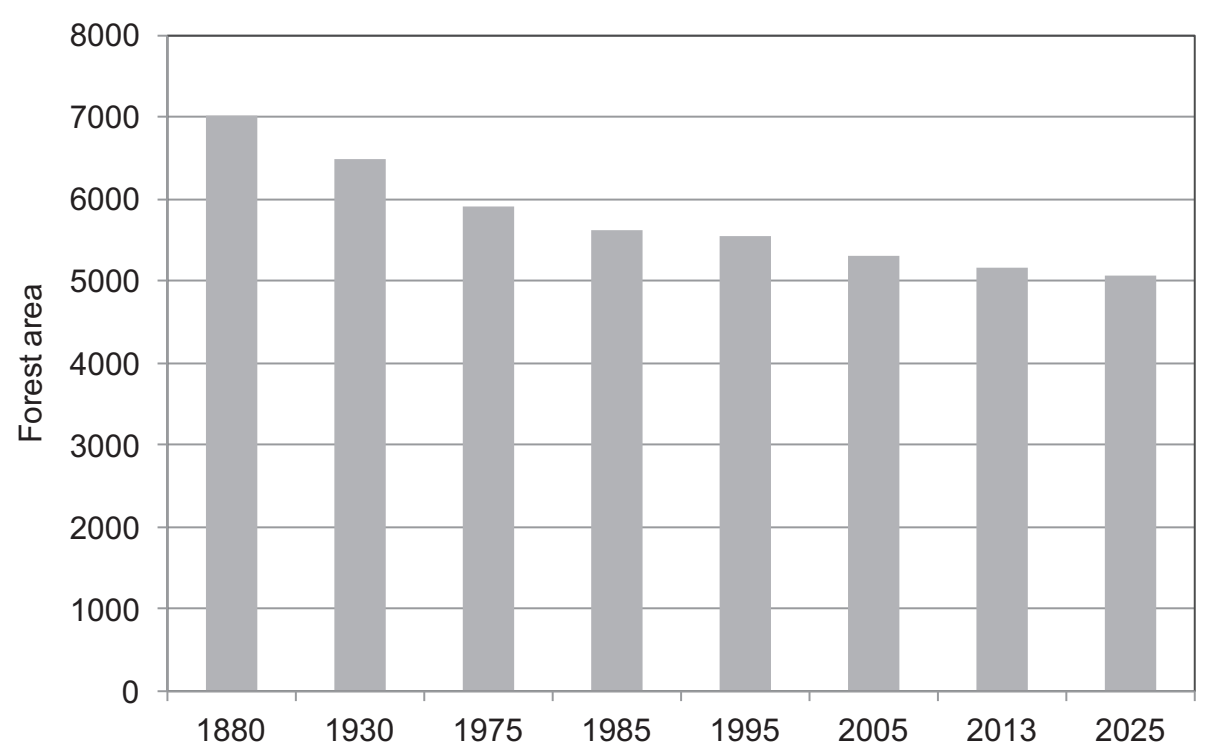

Figure 8. Areal extent of forest cover in protected areas of the Northeast from 1880 to 2025.

Table 6. Cramer coefficients for future forest cover change.

\begin{tabular}{|c|c|c|c|c|c|}
\hline State & Elevation & Slope & $\begin{array}{l}\text { Distance to } \\
\text { road }\end{array}$ & $\begin{array}{c}\text { Distance to } \\
\text { settlement }\end{array}$ & $\begin{array}{l}\text { Distance to } \\
\text { water-bodies }\end{array}$ \\
\hline Assam & 0.5018 & 0.275 & 0.0512 & 0.011 & 0.1111 \\
\hline Manipur & 0.3083 & 0.4141 & 0.0058 & 0.0464 & 0.0948 \\
\hline Mizoram & 0.1353 & 0.4141 & 0.0253 & 0.0159 & 0.1837 \\
\hline Meghalaya & 0.2728 & 0.4381 & 0.0342 & 0.0074 & 0.4141 \\
\hline Nagaland & 0.1427 & 0.5012 & 0.0172 & 0.0139 & 0.1783 \\
\hline Andaman \& Nicobar & 0.3411 & 0.5158 & 0.1247 & 0.1077 & 0.1692 \\
\hline
\end{tabular}

2016a, b). Major causes of deforestation in Meghalaya are attributed to extensive mining, shifting cultivation and permanent agriculture. In Tripura and Nagaland, uncontrolled exploitation of forests, extensive cutting of bamboo and conversion of forests to permanent agriculture are the main threat for forests (Reddy et al. 2013). Results of the present study indicate a high rate of deforestation before 1995 and a lower rate of deforestation after 1995. Population statistics of Andaman \& Nicobar Islands from 1931 to 2011 showed a continuous population increase of 19,223 to 381,000 , and the population growth was more than $90 \%$ (http://censusindia.gov.in).

India has 590 protected areas - 500 wildlife sanctuaries and 90 national parks covering an area of $156,700 \mathrm{~km}^{2}$. At present, under the provisions of the act, $4.7 \%$ of the total geographic area of the country is devoted to in situ conservation (MOEF 2008) which has resulted in effective conservation of forests in many protected areas since the 1990s (Harikrishna et al. 2013; Satish et al. 2014; Dutta et al. 2016).
Table 7. Cramer coefficients for past forest cover prediction.

\begin{tabular}{lccc}
\hline Region & Elevation & Slope & $\begin{array}{c}\text { Distance to } \\
\text { settlement }\end{array}$ \\
\hline North India & 0.5421 & 0.114 & 0.0882 \\
Central India & 0.4006 & 0.4006 & 0.1181 \\
Northeast & 0.4229 & 0.1905 & 0.0132 \\
South India & 0.3627 & 0.2035 & 0.3767 \\
\hline
\end{tabular}

Of the 43 selected protected areas in Northeast, only four, i.e., Manas, Sonai-Rupai, Nameri and Marat Longri are still undergoing deforestation (table 5). Among the protected areas, large-scale deforestation in Manas sanctuary has contributed to $47.3 \%$ of the total loss of forests, as predicted and mapped from 1880 to 2025 . Overall, the forest loss was estimated to be $1419(20.25) \mathrm{km}^{2}$ in the 1880-1985 period whereas 1985-2005 has evidenced a loss of $306 \mathrm{~km}^{2}$ in the protected areas. The period 2005-2013 showed forest loss of $140 \mathrm{~km}^{2}$ in protected areas of the Northeast (figure 8). 
The Green India Mission under the National Action Plan on Climate Change, 2008, advocated bringing one-third of the nation's geographic area under forest cover by afforestation of wastelands and degraded forest areas (Rosencranz and Lele 2008). Now, the major challenge is to focus on vulnerable areas for effective conservation of biodiversity, enhancement of carbon stocks and sustainable management of forests (Reddy et al. 2016a, b).

\subsection{Evaluation of drivers of deforestation}

There was a clear decline in the probability of deforestation with increasing elevation in every state in the Northeast India, but this effect was not obvious in the landscapes that are predominantly plains, especially in lower parts of Assam and Tripura. Forest loss decreases with the increase in slope, due to less accessibility to the forest. The probability of deforestation was inadequately explained by the distance to the main road and with the distance to the settlements.

Statistically significant landscape variables associated with forest cover change were used in the LCM model. The explanatory power of the variables was tested based on the Cramer's V statistic, which ranges from 0 (no relation between variables) to 1 (perfect relation between variables). According to the Cramer coefficients, the slope was strongest associated with deforestation in India $(\mathrm{V}=0.4124125)$, followed by elevation $(\mathrm{V}=0.3294)$, distance to water bodies $(0.202)$, the distance to roads $(\mathrm{V}=0.0310625)$. State-wise Cramer coefficients (Cramer's V) for future forest cover change is given in table 6 . In the past (1930), however, elevation was strongly associated with forest cover distribution, followed by slope and settlement (table 7).

Overall, Cramer's V for past forest cover prediction in India indicates that the spatial driver of elevation has the highest value $(0.432075)$ followed by the slope (0.22715) and distance from the settlement (0.14905).

Landscape features such as slope and the location of water bodies can influence the accessibility to a forest and consequently the susceptibility to conversion into a different land use (Bax et al. 2016). Elevation and distance to forest edge are proxies for the accessibility of the forest. When forest loss occurs, the progressive increase in the mean elevation can lead to a decrease in the deforestation rate (Apan and Peterson 1998).

Many studies have identified an increase in deforestation intensity with increasing population density, but in several cases, the effect was weak or not statistically significant (Vieilledent et al. 2013). Many political, socio-economic and ecological factors that are different from population density might explain deforestation intensity (Lambin et al. 2001).

\subsection{Model validation}

The predictive performance of the MLP neural network model was evaluated by comparing the model-predicted forest cover with the actual remote sensing derived forest cover map. The kappa statistic was used to compare the simulated forest cover maps for 2013 with the actual classified forest cover map for 2013 under the BAU scenario (table 8). Maximum possible unweighted kappa in the Northeast, given the observed marginal frequencies, is 0.996 , while the observed as proportion of maximum possible is 0.8312 . Maximum possible unweighted kappa in Andaman \& Nicobar Islands, given the observed marginal frequencies, is 0.9917, while observed as proportion of maximum possible is 0.7124 .

\section{Conclusions}

The present study investigated the distribution of forest cover in India by reconstructing the past forest cover and predicted the ever-continuing deforestation in selected parts of India with high deforestation rates. The overall predicted loss of forest cover by 2025 is estimated to be $2305 \mathrm{~km}^{2}$ in the Northeast and Andaman \& Nicobar Islands. The simulation scenario for the year 1880 showed a significant increase in forest area, whereas as a declining trend in the area was observed for 2025. Projections of deforestation provided by the present study can support biodiversity conservation, declaration of new protected areas, regional planning and adoption of mitigation measures for climate change.

Table 8. Kappa statistic for the simulated forest cover maps for 2013 with the actual remote sensing derived forest cover map for 2013.

\begin{tabular}{lcccc}
\hline \multirow{2}{*}{ Region } & Kappa & $\begin{array}{c}\text { Standard } \\
\text { error }\end{array}$ & Lower limit & Upper limit \\
\hline Northeast & 0.8279 & 0.0014 & 0.8252 & 0.8306 \\
Andaman \& Nicobar Islands & 0.7065 & 0.0112 & 0.6845 & 0.7285 \\
\hline
\end{tabular}




\section{Acknowledgements}

The present work has been carried out as part of ISRO's National Carbon Project. The authors are grateful to the ISRO-DOS Geosphere Biosphere Programme for financial support.

\section{References}

Apan A A and Peterson J A 1998 Probing tropical deforestation: The use of GIS and statistical analysis of georeferenced data; Appl. Geogr. 18 137-152.

Bax V, Francesconi W and Quintero M 2016 Spatial modelling of deforestation processes in the Central Peruvian Amazon; J. Nat. Conserv. 29 79-88.

Choudhari D K 2013 Uncertainty modelling for asynchronous time series data with incorporation of spatial variation for land use or land cover change; M.Sc. thesis, Indian Institute of Remote Sensing, Dehradun.

Clark N E, Boakes E H, McGowan P J, Mace G M and Fuller R A 2013 Protected areas in South Asia have not prevented habitat loss: A study using historical models of land-use change; PloS One 8(5) e65298.

Dutta K, Reddy C S, Sharma S and Jha C S 2016 Quantification and monitoring of forest cover changes in Agasthyamalai Biosphere Reserve, Western Ghats, India (19202012); Curr. Sci. 110(4) 508-520.

Eastman J R 2006 IDRSI 15 andes, In: Guide to GIS and Image Processing, Clark University, Worcester, MA.

FAO (Food and Agriculture Organisation of the United Nations) 2005 State of the world's forests; FAO, Rome.

Gadgil M and Guha R 1993 This fissured land: An ecological history of India; Univ. California Press.

Hansen M C, Stehman S V and Potapov P V 2010 Quantification of global gross forest cover loss; Proc. Nat. Acad. Sci. USA 107 8650-8655.

Harikrishna P, Reddy C S, Singh R and Jha C S 2013 Landscape level analysis of disturbance regimes in Protected Areas of Rajasthan, India; J. Earth Syst. Sci. 123 467-478.

Ingram J C and Dawson T P 2005 Technical Note: Interannual analysis of deforestation hotspots in Madagascar from high temporal resolution satellite observations; Int. J. Remote Sens. 26(7) 1447-1461.

Jha S and Bawa K S 2006 Population growth, human development and deforestation in biodiversity hotspots; Conserv. Biol. 3 906-912.

Lambin E F et al. 2001 The causes of land-use and landcover change: Moving beyond the myths; Global Environ. Change 11(4) 261-269.

Lambin E F 1994 Modelling deforestation processes: A review; EUR 15744 EN, TREES series B: Research Report No. 1; Joint Research Centre, Institute for Remote Sensing Applications; European Space Agency, Luxembourg, Office for Official Publications of the European Community, 128p.

Liebetrau A M 1983 Measures of Association (Quantitative Applications in the Social Sciences, No. 32); SAGE Publications, Newbury Park, CA.
Mas J F, Kolb M, Paegelow M, Olmedo M C and Houet T 2014 Modelling land use/cover changes: A comparison of conceptual approaches and softwares; Environ. Model. Softw. 51 94-111.

Meher-Homji V M 1989 History of vegetation of peninsular India; Man Environ. 13 1-10.

MOEF (Ministry of Environment and Forests) 2008 National Biodiversity Action Plan, Government of India, New Delhi, India, 100p.

Olander L P, Gibbs H K, Steininger M, Swenson J J and Murray B C 2008 Reference scenarios for deforestation and forest degradation in support of REDD: A review of data and methods; Environ. Res. Lett. 3 025011.

Puyravaud J P 2003 Standardizing the calculation of the annual rate of deforestation; For. Ecol. Manag. 177 593-596.

Ravindranath N H, Murthy I K, Joshi P, Upgupta S, Mehra S and Srivastava N 2014 Forest area estimation and reporting: Implications for conservation, management and REDD+; Curr. Sci. 106 1201-1206.

Reddy C S, Jha C S and Dadhwal V K 2013 Assessment and monitoring of long-term forest cover changes in Odisha, India, using remote sensing and GIS; Environ. Monit. Assess. 185 4399-4415.

Reddy C S, Jha C S, Dadhwal V K, Harikrishna P, Pasha S V, Satish K V, Dutta K, Saranya K R L, Rakesh F, Rajashekar G and Diwakar P G 2016a Quantification and monitoring of deforestation in India over eight decades (1930-2013); Biodiv. Conserv. 25 93-116.

Reddy C S, Rakesh F, Jha C S, Athira K, Sonali Singh, Alekhya V V L P, Rajashekar G, Diwakar P G and Dadhwal V K 2016b Geospatial assessment of long-term changes in carbon stocks and fluxes in forests of India (1930-2013); Global Planet. Change 143 50-65.

Ribbentrop B 1990 Forestry in British India; Indus Publishing Company, pp. 9-24.

Richards J F and Flint E P 1994 Historic land use and carbon estimates for south and southeast Asia 18801980 (ed.) Daniel R C, In: ORNL/CDIAC-61, NDP046, Oak Ridge National Laboratory, Tennessee, USA, $326 \mathrm{p}$.

Rosencranz A and Lele S 2008 Supreme Court and India's Forests; Econ. Polit. Wkly, pp. 11-14.

Satish K V, Saranya K R L, Reddy C S, Hari Krishna P, Jha C S and Prasada Rao P V V 2014 Geospatial assessment and monitoring of historical forest cover changes in Nilgiri Biosphere Reserve, Western Ghats, India (1920-2012); Environ. Monit. Assess. 186(12) 8125-8140.

Tian H, Banger K, Bo T and Dadhwal V K 2014 History of land use in India during 1880-2010: Large-scale land transformations reconstructed from satellite data and historical archives; Global Planet. Change $\mathbf{1 2 1}$ 78-88.

Vieilledent G, Grinand C and Vaudry R 2013 Forecasting deforestation and carbon emissions in tropical developing countries facing demographic expansion: A case study in Madagascar; Ecol. Evol. 3(6) 1702-1716.

https://clarklabs.org/terrset/land-change-modeler/. 